https://doi.org/10.5719/aub-g/70.1/5

\title{
A SYSTEM OF VALUES FOR THE IDENTIFICATION AND RANKING OF THE NATIONAL TOURISM HERITAGE IN ROMANIA
}

\author{
ELENA BOGAN ${ }^{1}$, TAMARA SIMON ${ }^{2}$, ANDREEA-LORETA CERCLEUX ${ }^{1}$
}

\begin{abstract}
The "cultural heritage" concept has continuously enriched itself, thus including several fields in its current meaning. A first major distinction is the one of the fields of tangible and intangible heritage. Our research work has shown us that there is a whole system of values, profiles and different contents that can determine the quality of a cultural and natural asset with economic and especially tourist importance. Each country has chosen a smaller or bigger set of criteria to appraise those assets that can be officially classified from the culture and nature fields. Also, the evaluation of the heritage determines the protection and conservation processes and starts from the types of values represented by the items, natural and cultural sites or the nonphysical heritage elements. The methodological difficulties related to the heritage evaluation arise exactly from the complex nature of these values (cultural, esthetical, political, economic) which are not determined once for all but they fluctuate in time, being influenced by contextual factors like economic or social forces, cultural trends.
\end{abstract}

Keywards: identification values, natural and cultural heritage, tourist importance

\section{Introduction}

The term "value" refers to the existing and potential positive characteristics of things, while for each object, building and each heritage site is associated a number of values. The versatility is thus one of the basic characteristics of heritage, this same heritage gaining also

\footnotetext{
${ }^{1}$ University of Bucharest, Faculty of Geography, E-mail: elena.bogan@geo.unibuc.ro; loreta.cercleux@geo.unibuc.ro;

2 CS I, E-mail: tami_simon2003@yahoo.com.
} 
symbolical, historical, esthetical, economic, etc. values. These values are not intrinsic or permanent. They are resulting from the interaction between object and context, the society choosing permanently what element has significance in the historical-geographical context. The values that are defining heritage have been considered initially the historical and esthetical ones.

There is a whole history about the problems and actions related to the cultural and natural heritage. The juridical recognition of the heritage importance took place only in 1954 along with the Haye Convention, meant to protect the cultural assets in case of armed conflict, updated in 1999 (UNESCO, http://portal.unesco.org/fr/ev.php/).

The first step was made with the General Conference of the U.N.O. for Education, Science and Culture, organised in Paris, in 1972, at its XVII ${ }^{\text {th }}$ session, where the participants concluded that the cultural and natural heritage is threatened by destruction, not only because of the normal degrading processes but also by the evolution of the social and economic life that is affecting it, through different phenomena of alteration and destruction. As a consequence, the first Convention of heritage protection and conservation at world level was issued. Starting with 1997, through the UNESCO's contribution the concept of spoken and non-material heritage were better defined. This step created the path to the maintenance and conservation of many cultural assets of humanity.

Later, at European level, the Granada Convention (Spain) was drafted in 1985 - this act was reflecting the changes of the analysis and evaluation of heritage, putting emphasis on the importance of the heritage conservation in the context of the urban development.

Later, in 2000, in Århus (Denmark) the event participants drew up the Convention of the landscape that defined the concept of landscape and the one of integrated conservation - concepts that are now widely accepted. Starting from 2000, the inclusion of the sustainable development and capitalisation concept inside the heritage protection policies started to be more and more common; such a concept is supporting responsible actions from the social and environment point of view.

During recent years, several documents with international character have been issued: The Convention on the protection of underwater 
cultural heritage in 2001, The Convention for the safeguard of the intangible cultural heritage in 2003, The Convention for the protection and promotion of the cultural expression diversity, in 2005, all these being signed in Paris (France). Along with the economic evolution, The Faro Convention for the value of the cultural heritage for society was drafted in October 2005 in Portugal.

On a world and especially European level, we can notice an increase of the role of urban and rural communities and the expert community in the decision-making process for the preservation and protection of the heritage, determined by the major changes in the former communist states but also in the countries with civilian and military conflicts. Consequently, communities notice an intensification of the continuous and coherent dialogues on the connexion between international, national and local interests and the concept of heritage.

New heritage assets have been identified (industrial, agricultural, archaeological, architectural) and the vision on the experts' role has evolved substantially, this role passing from that of an analyst and evaluator to the one of guide, educator and supporter of the community. In this new context, cultural routes, thematic trans-national itineraries, national and local interest urban and rural routes have been developed. The notion of "cross-border heritage" has become an important indicator and component of the sustainable conservation and capitalisation of the heritage.).

\section{Scientific contributions related to heritage}

Along with these global initiatives, we can note the work carried out by certain historians, art historians, curators and museum directors who have always supported the conservation and protection of cultural heritage. Some of these were the first to define the concept of historical monument. Most of them come from countries with a rich and valuable cultural and natural heritage, such as Austria, France, Italy, Great Britain, USA, Canada, Australia, etc.

Among all these, it is worth mentioning the Austrian art historian Alois Riegl (1858-1905) with his most valuable work "The modern cult 
of monuments, its essence and its genesis" (1903). He identified the values: historical, old age, commemorative, usage and innovation. Later, the American archaeologist and anthropologist William D. Lipe and T. A. Kohler published in 1984 an important article about heritage "Value and Meaning in Cultural Resources". The author is demonstrating that the term "heritage values" refers to the significances and values that individuals or groups of people associate with heritage (including collections, buildings, archaeological sites, landscapes and intangible expressions of culture, such as traditions).

These values have been a key factor in the justification of the protection and administration of heritage, although the perception of these has changed along time and there are distinctions between countries.

The ecologist Canadian Pierre Legendre (born in 1946) noticed clearly in relation to the cultural creations that these are "first of all our fellows and brothers, as they are the result of people's actions, as a valuable part of what is most precious for mankind" (Legendre, 1984). These are experiences of some generations that, through their works of art created proofs of their passage through history. The French Dominique Poulot, active contemporary art historian expresses the idea that heritage means "a body of precious works, which defines the symbolic universe of a social group, by favouring a small number of cultural objects that become symbols through which the group wishes to keep and pass on to the future generations" (Poulot, 2006). J-Y Andrieux (born in 1949) is a French art historian, specialist in the modern and contemporary architecture history, with specific preoccupations for heritage, in relation to society. He puts a lot of emphasis on the industrial heritage that should be kept, preserved and economically capitalised.

The concerns for the heritage problems are concentrated at the level of some institutes dedicated to heritage. In many countries in the world, heritage institutions have been created. There are famous and important heritage institutes in France, Great Britain, Italy, Belgium, Canada, Japan, Australia, etc. These include evaluation and restorationconservation laboratories and organise programmes of professional training in the field of cultural and natural heritage. 
In Romania, there is a national institute, in the form of a government institute, created in 2009 by the merging of the National Office of Historical Monuments and the National Institute of Historical Monuments. In 2011, the Institute of Cultural Memory - CIMEC was merged through the absorption with this institute.

The number of scientists concerned by the heritage aspect is much higher and many countries are putting more and more attention on this field. In the last 50 years, the increased attention given to the social and economic value of heritage has made useful the creation of new policies at international, national, regional and local level to manage this heritage and for the attraction of the largest possible visiting public. These policies were doubled by legislation and economy projects that should support the conservation, restoration and also integration of heritage assets in the economy circuit. In addition to management, the new preoccupation for the social value of heritage has influenced other sectors of this profession, such as the academic and technical environment in the art field.

\section{The structure of the heritage concept}

Analysing the evolution of the cultural heritage concept, we can notice that the definition of this term has gone through a continuous process of expansion and semantic transfer, identifying three major characteristics that are corresponding to the re-formulating stages:

- the extension of the inclusion capacity in the heritage of new assets that were not traditionally part of it, through a typological and thematic extension;

- the multiplication of the selection criteria for the cultural heritage through the inclusion, besides the historical and artistic values, of new values such as the identity, memorial and symbolical ones;

- the passing from the strict norm-objective approach to that one that extends over new assets that can offer other values and significations (phenomenon for the recognition of the intangible cultural heritage); 
- Through the UNESCO contribution the regulations require that a cultural asset should be considered an "oeuvre d'art" for a certain history period, showcasing a certain architecture and construction style, it should be representative for a certain human community (settlement), should be a symbol of a set of live events and traditions (https://whc.unesco.org/fr/criteres/2021). Also, it should be representative for certain natural phenomena or areas with a specific esthetical beauty or unique landscape.

In the identification and appreciation of the cultural heritage values, specialists use a series of criteria that correspond to the values represented by this heritage. Through using these, the identification, ranking and classification of historical monuments are done. Covering several systems of criteria from different countries (France, Canada, Italy) made it possible to select several types of general criteria, which are:

- the location criterion - in a certain natural or built space, at the level of a human settlement;

- the artistic criterion is reflected through the architecture quality and style, exterior and interior ornamentation;

- the scientific criterion that refers to the historical, architecture, style value that is characteristic of a certain historic period;

- the technical criterion - determined by the evolution of the building technique, materials used, the artisanal and technical quality of the execution;

- the historical criterion, through the reference of the cultural asset to the culture history, to the economy and society history, related to facts and individuals;

- the general criterion through the evaluation of the surroundings, the existent natural spaces, the quality of the environment.

Taking into consideration these criteria, we notice that in the recent decades of the $X X^{\text {th }}$ century, the phenomena of extending the structure and typology of the cultural heritage with new assets appeared, some of them dating from modern times with the passing from an isolated monument to cultural complexes, sites and landscapes; at the same time, new heritage fields (intangible and live works of art) are added. A special place is held by the participations of human communities from 
the urban and rural environment together with specialists and economic actors preoccupied by the conservation of heritage as well as the passage from conserving the heritage as an obligation and financial support to approaching heritage as a resource inside the sustainable development.

\section{Materials și methods}

The idea to draw up a synthesis of the values used to identify and rank the assets of the cultural and natural heritage has started after a long experience of the authors in the cultural tourism research in Romania. In order to tackle this new research theme, they started strictly from the qualitative aspect and less from the quantitative one. For this purpose they used the selective documentation - through this one, several articles and studies (Romanian and foreign) referring to the aspects of tackling and analysing cultural and natural assets in Romania have been selected and read.

The existent types, completed with the determination of the sustainable capitalisation characteristics have been analysed. Later, the legislation concerning the cultural heritage and biodiversity in Romania has been studied, in order to identify the real possibilities of socioeconomic capitalisation for the national heritage assets in Romania.

The analysis was centred on qualitative researches that are done in any stage of the studying process of a problem, their main aim being that of clarifying the nature of this problem and to offer quality information. After the identification of all the heritage values, they were able to give a certain number of points for each determined value. More than that, this method has allowed the identification of those assets which have real tourist values.

The logical background used more in management has been used here to put in the same context the existing types of heritage, their characteristics and the value system that can emerge. The values that are resulting can better explain the differences that exist between the heritage assets. More than that, it determines the degree of durability of the heritage for different design projects and for the development of economic activities. The more heritage values a heritage asset has, the 
more vulnerable it is for an economic and social exploitation and a special emphasis should be put on the restoration-conservation. In this context, the constant evaluation of results from the point of view of the entrepreneur and that of the owner counts very much.

The cultural and natural assets represent the cornerstone of all the national and international conservation strategies, being kept for the functioning of the local economies and ecosystems, to serve as a support for the development of new activities and jobs. Cultural and natural assets are functioning as landmarks through which we could understand the transmission of cultural patterns from a generation to the other and human's interaction with the natural world.

At a European level, policy-makers try to capitalise through tourism these heritage assets through the support and diversification of tourist activities. In this context, sustainable tourism promotion and development activities are supported, with an emphasis on the cultural and nature tourism.

From this point of view, the present article is proposing to show which are the benefits on the long term of a complex value system for Romania, for the better capitalization and ranking of all the cultural and natural resources that exist at the level of the national territory.

\section{Applying the value system for the inventory and identification of the cultural heritage in Romania}

Starting from 1990, important changes took place in the Romanian legislation regarding the cultural heritage and especially concerning the historical monuments. Thus, there is the law 182/2000 that settles a juridical status of the assets belonging to the mobile national cultural heritage, named from here on national cultural heritage.

This has a subsequent completion, through the Law 123/30.05.2017 for the modification and completion of Law 182/2000 concerning the protection of the mobile national cultural heritage. There is also, the Government Ordinance no. 27/1992 concerning some measures for the protection of the national cultural heritage that is also setting a list of the main categories of historical monuments (http://legislatie.just.ro/ Public/DetaliiDocument/181120). 
The latter was completed through the Order of the minister of culture no. 2183/2007 for the approval of the Methodology for the financial evaluation of the prejudice to the immobile national cultural heritage - historical monument or archaeological site (http://cimec.ro/ legislatie/legislatie-culturala.html). It was followed by the Order of the minister of culture no. 2260/18.04.2008 on the Methodological norms of ranking and inventory of historical monuments and the Order of the minister of culture no. 2684/2003 regarding the approval of the Methodology of creating the obligation regarding the usage of the historical monument and its contents.

Based on the evaluation of the existing legislation in Romania, the following criteria are used in the process of inventory, classification and ranking of buildings: the criterion of antiquity, the criterion of artistic and urban architectural value, the criterion of frequency as rarity and authenticity, the symbolic memorial criterion.

For the immobile heritage the criteria are identified by age, frequency of objects, their state of conservation. For the cultural landscapes, the criteria of traditional characteristics, of perennial age over time with emphasis on the element of historical antiquity, transience and modernity are used.

Historical monuments are classified in the following categories: a) A category - monuments of exceptional national value, representative for the Romanian civilisation at a world level; b) B category - monuments of national value; c) $\mathrm{C}$ category - monuments that are representative for a certain area, epoch, style, author, ethnographic area. The immobile cultural assets that are not classified in the categories A, B or C are considered common cultural assets. On the list - National cultural heritage divided by counties - are present only the A and B categories

The issue of reconsidering heritage supposes a detailing action of the physical and historical context of the monument through which are determined the conservation actions of historical buildings that are in danger because of the rhythm of the urban modernisation. The existence of a small group of valuable buildings becomes evident and generates the creation of the concepts - 'urban landscape' and 'street landscape'. 
The evaluation of the cultural heritage is a complex process with different stages which are inter-dependent. A first stage of the identification and description of the cultural asset is determined by the motivation/purposes of the protection and the groups involved (specialists, society, etc.). During this first stage, a descriptive sheet containing also images is done for one asset.

The second stage of the analysis and evaluation aims to find values related to its cultural significance and importance, its typology, structure, but also includes the analysis of the physical condition of the heritage object as well as the analysis of its management. The last stage refers to the synthesis of the analysis performed by the experts, in order to establish the decision-making framework for classification and prioritisation.

The result is a logical consequence of the data and information gathered and includes: setting policies, setting objectives, developing strategies, synthesising and preparing the protection plans. Over time, this result is constantly monitored, analysed and reviewed by stakeholders in the restoration, conservation and economic capitalisation of the cultural and natural heritage.

\section{Drawing up the value system in the analysis and evaluation of the cultural heritage}

The determination of the patrimony values is addressed to the application, in time and space, of all the methodologies and strategies used for attracting the heritage goods in the social and economic circuit, trying to capture the variety of these aspects. From the analysis of the cultural heritage assets in Romania, of the way to realise an inventory, identification and classification, the research carried out by the authors has led to the realisation of a complex set of values through which a better appraisal of the heritage assets is made (table no. 1). 
The value system applied in the natural and cultural heritage

\begin{tabular}{|c|c|c|}
\hline No. & Type of value & \begin{tabular}{|l|} 
Significance \\
\end{tabular} \\
\hline 1. & $\begin{array}{l}\text { Identity and } \\
\text { inheritance } \\
\text { value }\end{array}$ & $\begin{array}{l}\text { Natural and/or cultural asset that defines an urban or } \\
\text { rural community, an architecture style, artistic or } \\
\text { traditional style, a natural or cultural landscape, all } \\
\text { being elements forwarded for the benefit of future } \\
\text { generations, etc. }\end{array}$ \\
\hline 2. & $\begin{array}{l}\text { Authenticity } \\
\text { and rarity value }\end{array}$ & $\begin{array}{l}\text { Cultural asset and/or special structure characteristics, } \\
\text { presentation that confers it a special importance, in } \\
\text { comparison with others. Ex. C. Brancusi's (1876-1957) } \\
\text { sculptures from the Tg. Jiu municipality }\end{array}$ \\
\hline 3. & $\begin{array}{l}\text { Symbolical } \\
\text { value }\end{array}$ & $\begin{array}{l}\text { Natural and/or cultural asset that represent indirectly } \\
\text { (conventionally or in the virtue of an analogical } \\
\text { correspondence) an object, a being, a notion, an idea, a } \\
\text { quality. }\end{array}$ \\
\hline 4. & $\begin{array}{l}\text { Historical and } \\
\text { documentary } \\
\text { value }\end{array}$ & $\begin{array}{l}\text { Natural and/or cultural asset conditioned by the old } \\
\text { age, given by the period when it becomes known; it } \\
\text { can start from the primitive period up to the } \\
\text { contemporary period }\end{array}$ \\
\hline 5. & $\begin{array}{l}\text { Architectural or } \\
\text { artistic value }\end{array}$ & $\begin{array}{l}\text { A cultural asset that belongs to a certain style of } \\
\text { architecture and art. It can be applied to the natural } \\
\text { ones that are planned as parks and private and public } \\
\text { gardens. }\end{array}$ \\
\hline 6. & $\begin{array}{l}\text { Scientific and } \\
\text { technical value }\end{array}$ & $\begin{array}{l}\text { Cultural or natural asset that comprises certain } \\
\text { realisation techniques, as part of a science evolution, } \\
\text { for a natural asset; this also includes special flora or } \\
\text { fauna species or endemic ones }\end{array}$ \\
\hline 7. & $\begin{array}{l}\text { Commemorative } \\
\text { value }\end{array}$ & $\begin{array}{l}\text { Cultural asset that offers a celebration of the memory } \\
\text { of a personality, of an event, historical place; the } \\
\text { nature monuments with an old age can have } \\
\text { commemorative value (ex. The lime-tree belonging to } \\
\text { M. Eminescu). }\end{array}$ \\
\hline 8. & $\begin{array}{l}\text { Memorial and } \\
\text { author value }\end{array}$ & $\begin{array}{l}\text { Cultural asset having most often the status of a } \\
\text { monument, built in the memory of an event or a } \\
\text { personality. Also, it can include cultural assets created } \\
\text { by artistic or cultural personalities. Natural assets } \\
\text { refer to those protected areas that were created by } \\
\text { naturalists and ecologists or by some representatives }\end{array}$ \\
\hline
\end{tabular}




\begin{tabular}{|c|c|c|}
\hline No. & Type of value & Significance \\
\hline & & of local communities. \\
\hline 9. & $\begin{array}{l}\text { Political and } \\
\text { military value }\end{array}$ & $\begin{array}{l}\text { Cultural assets that represent the political power in } \\
\text { different historical ages of countries, or fortifications } \\
\text { and defence military constructions, ex. The Marasesti } \\
\text { Mausoleum, built for the heroes who died in the first } \\
\text { World War. }\end{array}$ \\
\hline 10. & $\begin{array}{l}\text { Religious and } \\
\text { spiritual value }\end{array}$ & $\begin{array}{l}\text { Cultural asset that is an institute that practices } \\
\text { religious cults or that refers to a set of ideas and } \\
\text { feelings that characterise a people, ethnic group from } \\
\text { the point of view of the spiritual life, of the specificity } \\
\text { of its culture }\end{array}$ \\
\hline 11. & $\begin{array}{l}\text { Business and } \\
\text { social value }\end{array}$ & $\begin{array}{l}\text { Cultural and natural assets can be the support basis } \\
\text { for some economic activities, from agriculture, } \\
\text { tourism, transport and local trade to local art\&craft } \\
\text { products, gastronomy, etc. Socially, it can help create } \\
\text { new jobs and a rise in community and individual } \\
\text { revenues, life quality. }\end{array}$ \\
\hline 12. & $\begin{array}{l}\text { Tourist and } \\
\text { recreational } \\
\text { value }\end{array}$ & $\begin{array}{l}\text { Cultural and natural assets can become a } \\
\text { development source for niche tourism types, more } \\
\text { and more demanded by many tourist categories. The } \\
\text { discovery, visitation and recreation side of these } \\
\text { assets is more and more demanded. }\end{array}$ \\
\hline 13. & Esthetical value & $\begin{array}{l}\text { Cultural and/or natural assets that, through their } \\
\text { beauty, create admiration, positive feed-back, } \\
\text { appreciation and can turn people into constant } \\
\text { visitors of such places and assets Ex. The Culture } \\
\text { Palace in the Iasi municipality, the Peles Castle in } \\
\text { Sinaia. }\end{array}$ \\
\hline 14. & Emotional value & $\begin{array}{l}\text { Natural and/or cultural assets that can determine a } \\
\text { diversity of affective feelings of medium intensity and } \\
\text { short duration, expressing the experience of } \\
\text { contemplation and positive feelings of joy, satisfaction } \\
\text { in front of these places. }\end{array}$ \\
\hline 15. & $\begin{array}{l}\text { Educational and } \\
\text { formation value }\end{array}$ & $\begin{array}{l}\text { Both types of assets can contribute to the gathering of } \\
\text { new theoretical and practical data, on the education } \\
\text { and professional level. From knowing each asset, } \\
\text { something can be learnt or something can be corrected } \\
\text { at spiritual or educative level. Any monument or } \\
\text { museum, collection or memorial house can have such }\end{array}$ \\
\hline
\end{tabular}




\begin{tabular}{|c|c|c|}
\hline No. & Type of value & Significance \\
\hline & & a value through well organised actions. \\
\hline 16. & $\begin{array}{l}\text { Associative and } \\
\text { usage value }\end{array}$ & $\begin{array}{l}\text { Cultural and/or natural assets can be capitalised in } \\
\text { different ways, with beneficial results, when put } \\
\text { together and not separately. This aspect can be put } \\
\text { into practice at the level of urban and rural } \\
\text { settlements that can create theme actions, routes and } \\
\text { itineraries for tourists. }\end{array}$ \\
\hline 17. & Landscape value & $\begin{array}{l}\text { Natural and/or cultural assets that form an artistic } \\
\text { complex that can be noticed in one look; view-spot; } \\
\text { physical aspect of a territory, resulting from the } \\
\text { combination of natural factors with 'antropic' factors }\end{array}$ \\
\hline 18. & Museum value & $\begin{array}{l}\text { Cultural and/or part of the natural assets, more } \\
\text { vulnerable, can be kept as exhibits, in museums, } \\
\text { botanical and zoological gardens. Museums are the } \\
\text { most trustful institutions in the presentation of the } \\
\text { human and natural history, of the collective memory. }\end{array}$ \\
\hline 19. & Universal value & $\begin{array}{l}\text { Natural and/or cultural assets can have exceptional } \\
\text { characteristics that go beyond state or regional } \\
\text { borders and give them a unitary character of high } \\
\text { value. The recognition of this value is made through } \\
\text { the UNESCO Cultural and natural heritage }\end{array}$ \\
\hline 20 & $\begin{array}{l}\text { National, } \\
\text { regional and } \\
\text { local value }\end{array}$ & $\begin{array}{l}\text { Natural and/or cultural assets can have characteristics } \\
\text { with different degrees of importance, covering } \\
\text { different territories related to surface and } \\
\text { geographical position. }\end{array}$ \\
\hline 21. & $\begin{array}{l}\text { Monument } \\
\text { value }\end{array}$ & $\begin{array}{l}\text { Natural and/or cultural assets can present } \\
\text { characteristics with different degrees of importance } \\
\text { but also with several gathered values that can bring } \\
\text { about the status of monuments, with different ranking } \\
\text { categories, with an official recognition. }\end{array}$ \\
\hline 22. & Brand value & $\begin{array}{l}\text { A natural and/or cultural asset can be used through its } \\
\text { notoriety and many times through its quality of } \\
\text { monument as a representation of a tourist and } \\
\text { commercial product/service. Special brands increase } \\
\text { the performance of the business by influencing three } \\
\text { key groups of interested parties: clients, employees } \\
\text { and investors. }\end{array}$ \\
\hline
\end{tabular}


Determining the values of an asset or heritage asset, regardless of whether they are classified or not, involves going through several stages of work. This approach can be done by people with training in different fields - geographers, historians, archaeologists, architects, etc. The role of each is to highlight all the characteristics of a heritage asset and to apply the best solutions for a sustainable economic recovery.

\section{The applicability of the proposed value system}

For any country or geographic region, the heritage contributes and enriches the quality of the daily life. This includes an identity image but it also becomes a source of local patriotism and collective pride. Despite these, the cultural heritage is often fragile, vulnerable and sometimes is even threatened with disappearance from different reasons, like age, fashion tendencies, bad status of buildings or a high number of tourists who are visiting a site. If we want that the inheritance be transmitted in time and space, it must be protected.

Knowing the cultural heritage and promoting it are key factors for its sustainability. For most of us, cultural heritage is synonym with "historical monuments". But we need to take into consideration that it includes many rare objects kept in museums, collections and memorial houses and it also comprises characters, historical places, legends and myths and cultural backgrounds.

In order to understand, evaluate, classify and select the heritage goods, authorities need a system of heritage values that is applied in most of the countries with a rich and diverse cultural heritage. Some countries use 4-5 heritage values (Bulgaria, Romania, the Czech Republic, etc.) and others use 7-10 heritage values (Canada, France, Italy, Greece, Egypt, etc.).

The existence of a complete system of heritage values determines easier the importance of a heritage asset, shows its real value as a whole but also through the elements which compose it and determine its protection status. The more values it owns, the more vulnerable it becomes along time and expresses an amazing value for any heritage.

If for many levels for these heritage values the non-usage value is proposed, this was not mentioned in the created system as it was 
opposed to the 'usage' value. The non-usage eliminates the idea of value; if a heritage asset does not have this final usage value, it means that it is not included in an activity of economic and social capitalisation.

The whole proposed system of heritage values has the role to influence the urban development policies, the infrastructure of the communication ways, of direct investments in economy. This is happening as any locality, urban or rural has a certain demographical, economic and cultural development dynamics.

The more a cultural or natural asset owns more heritage values, the more it needs a better integration in the new context of modernising a locality. The high number of such values will determine that a cultural asset be harder to demolish or ranked from the economy point of view, with a maximum profit for a certain land. Then, its economic capitalisation will be more carefully supervised to reduce any constructive or decorative degradation. The same aspect is valid also for the natural heritage in the meaning that there will be some limits in its economic capitalisation.

For the goods included in the natural heritage, these values are based on the number, structure and re-apparition of rare species, besides their genetic importance. Here the strong support of the landscape, scientific, rarity, national, regional and local, association value is coming up, as a capitalisation in the tourism field.

More than that, this system brings ahead a better knowledge and evaluation of the cultural and natural heritage goods, a better appraisal and ranking. Also, they notice the phenomenon of re-settling an urban and architectural continuation but also of a present biodiversity, of a coherent and sustainable administration of the territory in any locality.

The management interventions in the heritage field should be the result of a deep reflection process, representing, for a certain site, the analysis of problems, the emphasis of objectives, the choice and implementation of the necessary technical operations for realising these and finally, to evaluate their success through scientific monitoring. Managing a heritage asset is a dynamic process that needs to adapt constantly to the evolution of the human society in a certain territory. 
The management objectives for the capitalisation and conservation of the heritage must take into account this system of heritage values. Monitoring in time and space is making possible the inventorying and monitoring of its evolution in direct relation with the economic, social and cultural interests. This can make possible the verification that the general existence and functionality of a heritage has been restored, thanks to the management measures that are applied.

\section{Conclusions}

From the whole research work is resulting a multiple historical, material, spiritual, traditional and physical dimension of the assets that compose the national cultural heritage, at a technical level but also from the symbolical point of view, these representing an expression of the national values, beliefs and traditions, as, mainly, the heritage culture and values are the solid and definitive basis of a nation's identity. The present values are putting some essential aspects intro light:

- the values show the diverse structure and the complexity of the assets that are part of the cultural and natural heritage of the country

- the values show that the national heritage includes all its components and that they need to be evaluated and capitalised as complex entities, in connection with the others and not as singular items;

- the values are dynamic and can change in time; some can become dominant in comparison to others that can become less relevant;

- the values can associate with each other so that a heritage asset can cover several values, fact that increases its importance and universality.

The number of criteria and values in the identification and analysis of the Romanian heritage is extremely limited and it should be extended. In this context, the general value of many cultural assets would increase. This would also create a better economic capitalisation, especially in tourism. Currently there are several cultural assets at the level of urban and rural communities that have been too little analysed and evaluated. 
Relying on the aspects presented above, we can conclude that the cultural heritage is a field in continuous extension and development that makes the identification and settlement of its values difficult. Practically, each changing of the cultural and natural assets leads to the increase or decrease of its values in time and space.

Consequently, the evaluation of the natural and cultural heritage and its possibilities of economic capitalisation will be even more difficult. The more values it owns, the better is the capitalisation on the economic and social level, especially in the tourism field. But this capitalisation has some limits, because of the possibilities linked to destruction degrading and ruin which can appear through the superusage process.

\section{REFERENCES}

Legendre, P. 1985, L'inestimable objet de la transmission. Étude sur le principe généalogique en Occident, Paris, Fayard, p. 23.

Lipe, W.D., Kohler T.A., Value and Meaning in Cultural Resources, publishing in Approaches to the Archaeological Heritage, ed. Henry Cleere, Cambridge University Press, Cambridge, England, pp. 1-11.

Oberlander-Târnoveanu, I. 2009, A future for the past, a good practice guide for preserving cultural heritage, Digital Edition http://www.cimec.ro/Arheologie/ Oberlander-un-viitor-pentru-trecut/index.html.

Petrescu, I. 2008, The global dimension of sustainable development management, Foundation Romania de Maine Publishing House, Bucharest.

Poulot, D. 2006, Une histoire du patrimoine en Occident, Paris, PUF, p. 10.

Riegl, A. 1903, Le culte moderne des monuments. Son essence et sa genèse [Alois Riegl. Trad. de l'allemand par Wieczorek D. Avant-propos de Françoise Choay]. Paris: Éditions du Seuil 1984.

Throsby, D. 2012, The economics and culture policy, Cambridge: Cambridge University Press.Brody, SD, Peck, BM, Highfield, WE 2004, Examining localized patterns of air quality perception in Texas: A spatial and statistical analysis, Risk Analysis 24, 1561-1574.

*** ICOMOS and WTO (1993); Tourism at World Heritage Cultural Sites: The Site Manager's Handbook; 2nd edition, Madrid: World Tourism Organization.

**** Law 182/2000 concerning the protection of the mobile national cultural heritage.

*** Law 422/2001 concerning the protection of historical monuments.

*** Convention pour la protection des biens culturels en cas de conflit armé, avec Règlement d'exécution 1954, Deuxieme Protocole, La Haye, le 26 mars 1999. 
http://portal.unesco.org/fr/ev.php/

http://legislatie.just.ro/Public/DetaliiDocument/181120

http://cimec.ro/legislatie/legislatie-culturala.html

https://whc.unesco.org/fr/criteres/2021

http://www.cimec.ro/Muzee/Oberlander-observatii-critice-privind-normele-declasare/index.html

http://revista.universuljuridic.ro/patrimoniul-cultural-un-subiect-actual/ 